\title{
POLYMERASE CHAIN REACTION DETECTION OF ADENOVIRUS DNA SEQUENCES IN HUMAN LYMPHOCYTES
}

\author{
Aufra A. Araújo ${ }^{1,2}$; Jonny Yokosawa ${ }^{1,2}$; Edison L. Durigon ${ }^{1}$; Armando M. Ventura ${ }^{1 *}$ \\ ${ }^{1}$ Departamento de Microbiologia, Instituto de Ciências Biomédicas, Universidade de São Paulo, São Paulo, Brasil. \\ ${ }^{2}$ Current address: Molecular and Immunodiagnostic Section, Centers for Disease Control and Prevention, Atlanta, GA, USA
}

Submitted: September 12, 2000; Returned to authors for corrections: December 11, 2000; Approved: May 25, 2001

\begin{abstract}
Human lymphoid cells frequently carry adenoviruses and DNA sequences have been identified in peripheral blood lymphocytes by Southern blot and PCR, although these cells are not permissive for virus replication, suggesting persistence of the viral genome. In order to investigate this phenomenon we screened non-symptomatic volunteers for adenovirus DNA presence and E1A gene expression. DNA samples extracted from peripheral blood mononuclear cells of 51 volunteers were submitted to PCR using primers for a conserved hexon sequence, followed by nested PCR. Adenovirus sequences were detected in 27 samples (52.9\%). After more than one year, new samples of these positive volunteers were analyzed and in $70.8 \%$ of the cases the result was maintained. Since this could be due to a possible persistence we checked if the early gene E1A was involved analyzing its expression by RT-PCR. For that purpose we developed a pair of primers to target a conserved region in the E1A gene. The RT-PCR results for E1A were negative for all samples. Using these primers it was possible to detect adenovirus sequences directly by PCR in DNA samples and we found $84 \%$ agreement in comparison to the hexon analysis. Our data suggest a high occurrence and persistence of adenovirus genome sequences in human lymphoid cells, and an indication that a region other than E1A is involved in persistence. We also can say that E1A gene is a good choice for amplification as a tool in adenovirus detection, avoiding the high risk of contamination in the nested PCR procedure necessary for hexon detection.
\end{abstract}

Key words: adenoviral infection, viral persistence, lymphocytes, nested PCR assay

\section{INTRODUCTION}

Adenoviruses are ubiquitous and responsible for a wide variety of clinical illnesses ranging from mild upper respiratory diseases in children to large outbreaks of pneumonitis, conjunctival disorders, gastro-enteritis, and skin rashes (9). There is evidence that adenovirus can establish persistent infections in asymptomatic individuals (15). Human lymphoid cells have been reported to carry adenoviruses and its DNA sequences have been identified in peripheral blood lymphocytes (7). Since these cells are not permissive for virus replication these findings suggest persistence of adenovirus in circulating lymphocytes. Adenovirus presence could influence the susceptibility of their carrier cells to a subsequent viral infection such as HTLV and HIV, due to the fact that adenovirus early genes are reported to influence transcriptional activity from their LTR regions $(2,16)$. We decided to search for adenovirus presence in a higher number of donors and using a more sensible detection technique, to have a hint of the possible epidemiological meaning of adenovirus presence in peripheral blood mononuclear cells (PBMCs). Polymerase chain reaction (PCR) has been used for laboratory diagnosis of adenoviral infection in epidemiological studies. The sensitivity of PCR amplification compares favorably with antigenic assays (6). Hierholzer and co-workers (6) described a sensitive method of detecting adenoviruses by PCR, with generic primers targeting the hexon gene, followed by a detection system based on liquid-phase hybridization and time-resolved (TR)

\footnotetext{
* Corresponding author. Mailing address: Avenida Professor Lineu Prestes, 1374, Departamento de Microbiologia, ICB II, USP, Cidade Universitária
} 05508-900, São Paulo, SP, Brasil. Fax: (+5511) 3818-7354, E-mail: amventur@icb.usp.br 
fluorometry. We used the same primers followed by nested-PCR instead of TR fluorometry, to analyze the presence of adenovirus DNA sequences in PBMCs of non-symptomatic volunteers. In addition, we wanted also to address which region of adenovirus genome would be active and involved in persistence. For that purpose a pair of primers targeting conserved domains 1 and 2 of E1A gene $(10,12)$ was developed. We used these E1A primers for RT-PCR to look for expression, and also in a direct PCR assay for a comparison with the hexon detection data.

\section{MATERIALS AND METHODS}

Study participants were 51 non-symptomatic adult volunteers, between 22 and 58 years of age. Samples were collected after informed consent from the volunteers. PBMCs were isolated from heparinized blood specimens $(10 \mathrm{ml})$ by Ficoll-Hypaque (Organon Teknica Co., Durham, NC) density gradient centrifugation, resuspended in $10 \mathrm{ml}$ of phosphate-buffered saline (PBS) and washed twice with PBS. From the positive volunteers 27 new samples were collected 17 to 19 months later.

Transient transfection in Hep2 cells was used to have a positive control of PCR, nested PCR and RT-PCR assays. Hep2 cells (2X106) grown in $75 \mathrm{~cm}^{2}$ culture bottles were transfected with $10 \mu \mathrm{g}$ of plasmid pE1A (16) complexed to lipofectin (GIBCO, Gaithersburg, $\mathrm{MD})$ as recommended by the manufacturer. After $48 \mathrm{~h}$ at $37^{\circ} \mathrm{C}$ in a $5 \% \mathrm{CO}_{2}$ incubator the cells were collected.

DNA extraction was carried out by resuspending the cells in $500 \mu \mathrm{l}$ of lysis solution (0.1 M Tris-HCl pH 8.0; 0.1 MEDTA; 0.1 M $\mathrm{NaCl} ; 1 \%$ SDS) and Proteinase K (Boheringer-Mannheim, Indianapolis, IN) to a final concentration of $0.1 \mathrm{mg} / \mathrm{ml}$. The mixture was incubated for 1 hour at $56^{\circ} \mathrm{C}$, and proteins were extracted twice with phenol-chloroform (1:1) (GIBCO, Gaithersburg, MD). DNA was precipitated and resuspended in $300 \mu \mathrm{l}$ of TE (Tris 10 mM pH 8.0; 1 mMEDTA).

RNA extraction was carried out as previously described (17). Briefly, the cells were resuspended in 1,3 ml of solution A, prepared by mixing solution $\mathrm{B}$ ( $4 \mathrm{M}$ guanidinium isothiocyanate and $25 \mathrm{mM}$ sodium citrate $\mathrm{pH} 7.0$ ), water-saturated phenol and $2 \mathrm{M}$ sodium acetate ( $\mathrm{pH} 4.0)$ in a ratio of 1:1:0.1 and supplemented with $720 \mu \mathrm{l}$ of $\beta$-mercaptoethanol per $100 \mathrm{ml}$ of solution B. After cell lysis 0.13 $\mathrm{ml}$ of chloroform was added to the suspension, vortexed and placed on ice for $30 \mathrm{~min}$. The phases were separated by centrifugation at $12000 \mathrm{x}$ g for $20 \mathrm{~min}$ at $4^{\circ} \mathrm{C}$. RNA was precipitated and resuspended in $50 \mu \mathrm{l}$ of DEPC-treated water.

Primer sequences for PCR and nested PCR assays were taken from a 161 bp region of the $\mathrm{Ad} 2$ hexon gene sharing a high degree of nucleotide homology with the 47 human adenovirus serotypes (6). The sequences of the inner and outer pair of primers were: 332 , 5'-TGACTTTTGAGGTGGATCCATGG-3'; 333, 5'-GGTCT CGATGACGCCGCGGTGC-3'; and H-1, 5'-GCCGAGAAGG GCGTGCGCAGGTA-3'; H+2, 5'-TACGCCAACTCCGCCC ACGCGCT-3', respectively.
Primer sequences for E1A gene detection were based on human adenovirus type 2 . The primer CD1, 5'-TATGATTTAGACGTG3', maps to the positions of aa 47 to 51 in E1A conserved domain 1 and the primer CD2, 5'-CTCGTCGTCACTGGG-3', maps to the positions of aa 131 to 135 in E1A conserved domain 2. The location of the conserved domain positions was based in previous publications $(10,12)$. The sequences of the primers capable of detecting $\beta$-actin gene are: BA1, 5'-GTGGGGCGCCC CAGGCACCA-3' and BA4, 5'-TGGGTCATCTTCTCGCGGTT-3' (14). These primers were used in order to verify the quality of extracted DNA and RNA.

For PCR reactions, DNA was denatured at $95^{\circ} \mathrm{C}$ for 10 minutes and cooled on ice for 10 minutes immediately before use. $100 \mathrm{ng}$ (around 9000 cells) were added to a reaction mixture $(25 \mu \mathrm{l})$ containing buffer (20 mM Tris. $\mathrm{HCl} \mathrm{pH} \mathrm{8.4,50} \mathrm{mM} \mathrm{KCl),} 0.2 \mathrm{mM}$ of dNTPs (Pharmacia Uppsala, Sweden), $1.5 \mathrm{mM} \mathrm{MgCl}_{2}, 0.6 \mathrm{U}$ Taq DNA polymerase (GIBCO, Gaithersburg, MD), and $1.0 \mu \mathrm{M}$ of each pair of primers. The reaction mixtures were overlaid with two drops of mineral oil and submitted to temperature cycling in a DNA Thermal Cycler (Perkin-Elmer Cetus).

The cycling conditions were $94^{\circ} \mathrm{C}$ for $5 \mathrm{~min}$ and then for 35 cycles at $94^{\circ} \mathrm{C}$ for $1 \mathrm{~min}, 61^{\circ} \mathrm{C}$ for $1 \mathrm{~min}, 72^{\circ} \mathrm{C}$ for $1 \mathrm{~min}$ and a final $5 \mathrm{~min} 72^{\circ} \mathrm{C}$, for the primer pairs $\mathrm{H}-1 / \mathrm{H}+2$ (hexon $\mathrm{PCR}$ ), 332/333 (hexon nested PCR) or BA1/BA4 ( $\beta$-actin). Aliquots of $0.5 \mu \mathrm{l}$ from the PCR reactions were taken for the hexon nested PCR. To detect $\mathrm{E} 1 \mathrm{~A}$ gene $(\mathrm{CD} 1 / \mathrm{CD} 2)$ we used $94^{\circ} \mathrm{C}$ for $5 \mathrm{~min}$ and then 35 cycles of $94^{\circ} \mathrm{C}$ for $7 \mathrm{sec}, 60^{\circ} \mathrm{C}$ for $7 \mathrm{sec}, 72^{\circ} \mathrm{C}$ for $7 \mathrm{sec}$ and a final $5 \min 72^{\circ} \mathrm{C}$.

For the reverse transcription and PCR to detect b-actin or E1A expression, first strand cDNA was generated from $5 \mu \mathrm{l}$ of total RNA. After denaturation for $5 \mathrm{~min}$ at $94^{\circ} \mathrm{C}$, the reaction mixture $(25$ $\mu \mathrm{l})$ was set up to $50 \mathrm{mM}$ Tris. $\mathrm{HCl}(\mathrm{pH} 8.3), 75 \mathrm{mM} \mathrm{KCl,} 3 \mathrm{mM}$ $\mathrm{MgCl}_{2}, 0.5 \mathrm{mM}$ dNTPs (Pharmacia Uppsala, Sweden), 20 pmol of antisense primer, $4 \mathrm{U}$ RNAse inhibitor (Boheringer-Mannheim, Indianapolis, IN), and $200 \mathrm{U}$ of Superscript II Reverse Transcriptase (GIBCO, Gaithersburg, MD). The positive controls in this experiment were PCR products of plasmid pE1A, RT-PCR of Hep2 cells transiently transfected with pE1A and RT-PCR of HEK293 (5) cells and the negative control was Hep2 cells RT-PCR. The mixture was incubated at $42^{\circ} \mathrm{C}$ for $60 \mathrm{~min}$ and $70^{\circ} \mathrm{C}$ for $15 \mathrm{~min}$. An aliquot of $5 \mu \mathrm{l}$ of this reaction was used to set up a PCR reaction in the conditions described above.

Aliquots $(20 \mu \mathrm{l})$ of each PCR reaction were run on a $2 \%$ agarose gel, and DNA bands were stained with ethidium bromide. Strict precautions were followed to prevent contamination of the PCR assay. PBMC samples were manipulated in a separate room and PCR reactions were set up in a appropriate laminar flow hood (Heto-Holten, Denmark), decontaminated with UV light prior to use. Filtered pipette tips were utilized and gloves changed frequently for reagent and sample manipulations during the preparation of PCR mixtures. Appropriate negative and positive controls were incorporated into each PCR assay. 


\section{RESULTS}

Genomic DNA was extracted from PBMCs from heparinized blood of 51 volunteers and $100 \eta \mathrm{g}$ of each DNA sample was used in a PCR assay to amplify a segment of $\beta$-actin gene, in order to verify the integrity of these samples. All the analyzed samples presented the expected DNA product of 300bp (not shown). These samples were then analyzed for the presence of adenovirus genomes by a PCR targeting hexon gene. As can be seen in the Fig. 1A, the amplified product of $161 \mathrm{bp}$ was observed only in the positive control (Ad2 DNA). After nested PCR, we observed the amplified product of $107 \mathrm{bp}$ in 27 of 51 (52.9\%) analyzed samples, as exemplified in Fig. 1A.
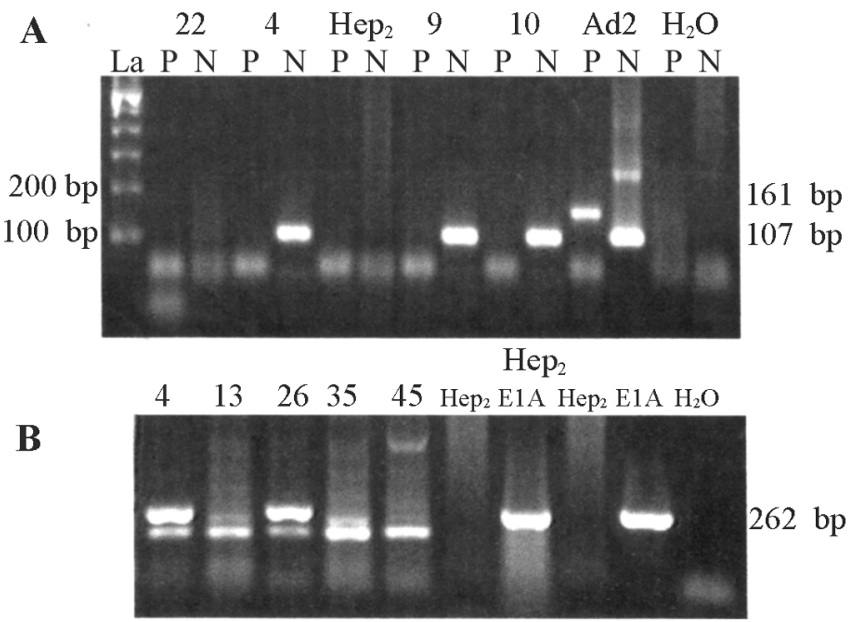

$\begin{array}{llllllll}\text { La } & 4 & 9 & 10 & 13 & 16 & 17 & \text { E1A Hep }_{2} \text { HEK Hep }\end{array}$ E1A

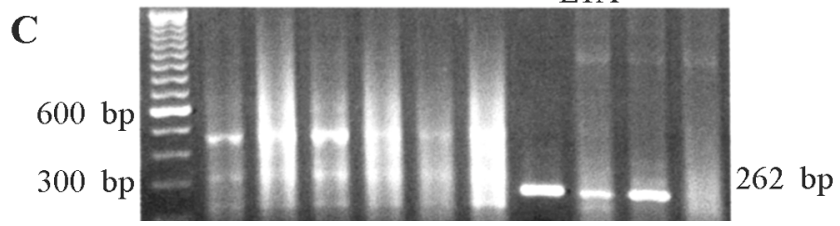

Figure 1. Examples of adenovirus gene detection in PBMCs. (A) Gel electrophoresis of PCR (P) and nested PCR (N) products, using primers for hexon gene: negative (lane 22); positive (lanes 4, 9, 10); negative controls $\left(\mathrm{H}_{2} \mathrm{O}, \mathrm{Hep} 2\right)$; positive control ( $\left.\mathrm{Ad} 2\right)$, with $161 \mathrm{bp}$ (P) and $107 \mathrm{bp}(\mathrm{N})$ DNA products. (B) Gel electrophoresis of PCR products using primers for E1A gene: negative (lanes 13, 35, 45); positive (lanes 4, 26); negative controls $\left(\mathrm{H}_{2} \mathrm{O}\right.$, Hep2). The positive controls are plasmid pE1A (E1A) and Hep2 cells transiently transfected with pE1A (Hep2 E1A), which gives 262 bp products. (C) Gel electrophoresis of RT-PCR products using primers for E1A gene: negative samples (lanes 4, 9, 10, 13, 16, 17); negative control (Hep2). The positive controls are products of plasmid pE1A PCR (E1A), RT-PCR of Hep2 cells transiently transfected with pE1A (Hep2 E1A) and RT-PCR of HEK 293 cells (HEK). The molecular weight marker in A and C (La) is a 100 bp DNA ladder.
After 17 to 19 months, new blood samples from positive individuals were collected for DNA and RNA extraction. In these samples a new nested PCR analysis was done for hexon detection and in $70.8 \%$ (17 of 24) of the cases the hexon gene was detected (Table 1). In these samples the percent of Ad genome presence was higher and we analyzed them for the possible presence and involvement of E1A in persistence. A PCR targeting conserved E1A gene sequences was devised (see Materials and Methods) for this purpose. As can be seen Fig. 1B and Table 1, there is an agreement of $83 \%$ in detection between the two targeted sequences.

Since E1A amplification was more sensible, due to direct detection by PCR (Fig. 1B), these primers could be good to search for E1A expression by RT-PCR. To set up the conditions for RTPCR E1A detection we used HEK293 cells (5), which is transformed by adenovirus type 5 E1 region, and Hep 2 cells

Table 1. Results of Nested PCR for Hexon gene and PCR for E1A gene detection in PBMCs from 27 positive volunteers in the first screening, collected after 17 to 19 months.

\begin{tabular}{|c|c|c|}
\hline $\begin{array}{l}\text { VOLUNTEERS } \\
\text { (Positive in the } \\
\text { First Screening) }\end{array}$ & $\begin{array}{c}\text { Hexon } \\
\text { Nested PCR }\end{array}$ & E1A PCR \\
\hline 1 & nd & nd \\
\hline 4 & + & + \\
\hline 9 & + & + \\
\hline 10 & + & + \\
\hline 13 & - & - \\
\hline 16 & + & + \\
\hline 17 & + & + \\
\hline 21 & + & + \\
\hline 22 & - & - \\
\hline 23 & nd & nd \\
\hline 24 & + & + \\
\hline 25 & + & + \\
\hline 26 & - & + \\
\hline 27 & + & + \\
\hline 28 & + & - \\
\hline 29 & - & - \\
\hline 30 & + & - \\
\hline 31 & - & - \\
\hline 32 & + & + \\
\hline 33 & + & - \\
\hline 34 & - & - \\
\hline 35 & - & - \\
\hline 36 & + & + \\
\hline 37 & + & + \\
\hline 38 & + & + \\
\hline 40 & + & + \\
\hline 45 & - & - \\
\hline
\end{tabular}

(+) presence or (-) absence of amplified products (nd) not done 
transiently transfected with a plasmid able to express E1A (see Materials and Methods). In Fig. 1C we can see the analysis of the controls and some of the samples by RT-PCR. We could detect $\beta$-actin expression in all samples (not shown) but no E1A expression.

\section{DISCUSSION}

Persistent adenovirus infection can be important in immunocompromised patients due to its potential reactivation. Adenovirus presence in PBMCs could also influence the susceptibility of cells to a subsequent natural infection by lymphotropic viruses such as HTLV and HIV $(2,16)$, or by viral vectors in gene therapy protocols. Attempts to maintain in vitro adenovirus replication in lymphocytes and monocytes for long time have failed (1). These cells have also poor sensitivity and show no citopatic effect upon adenovirus infection (8). Otherwise, some replication has been shown in short term human lymphocyte cultures (11). In vivo detection has been achieved by Southern Blot, and has shown $76.5 \%$ of detection in 17 samples of nonsymptomatic donors (7). More recently, Flomenberg and coworkers (3) used nested PCR for hexon gene detection in lymphocytes of 33 adult and 40 children free of disease symptoms, and 2 children with adenovirus fatal infection. These authors detected adenovirus in only one healthy child and the two infected, concluding that adenovirus persistence in human lymphocytes is unlikely.

In this work we also used nested PCR targeted to hexon gene to detect adenovirus in lymphocytes, but the primers were the ones described by Hierholzer and co-workers (6). These primers amplify a $107 \mathrm{bp}$ region, localized in the 3' region of hexon gene (sense primer nucleotides 10771 to 10787 in $\mathrm{Ad} 2$ ). In the study by Flomenberg and co-workers, the target sequence is in the 5' region (sense primer nucleotides 8051 to 8073 in $\mathrm{Ad} 2$ ). Our results indicate detection of adenovirus in $52.9 \%$ of 51 samples from nonsymptomatic donors, in agreement with Horvath and co-workers observations (Fig. 1A and Table 1). We then asked if in this positive sub-population the percentage of adenovirus presence would hold higher than in the first screened population. In the second screening (more than one year after) we had $70.8 \%$ positive samples (see Table 1), which aloud us to propose a high occurrence of adenovirus genomes in human PBMCs and that there is a tendency for persistence. The discrepancy of our findings and the ones by Flomenberg and co-workers (3) can be attributed to the different regions targeted in the hexon gene, which in our choice could reflect a higher degree of conservation among the most prevalent serotypes.

E1A is responsible for initial events in the activation cascade of adenovirus early genes (9), and consequently it may play a role in the persistent state of adenovirus genomes in PBMCs. We reasoned that in our second set of samples we could have a population enriched with persistent adenoviruses, and a higher chance to find E1A expressed. To analyze that we devised primers targeting conserved domains 1 and 2 of human adenovirus type 2 as described in Materials and Methods. Using these primers, we could detect adenovirus genomes in PBMCs DNA samples by PCR, without the need of a nested second amplification as for hexon targeted primers (Fig. 1). We found a good agreement of $83 \%$ between the two methods (Table 1), which justifies, in our opinion, the use of these primers as an alternative tool in adenovirus detection (avoiding the nested PCR). This difference is expected since these E1A primers based on adenovirus type 2 sequences, should be more specific for group $\mathrm{C}$ adenoviruses.

The primers for E1A proved to have a higher sensibility in detecting adenovirus sequences and could be used to search for E1A mRNAs. Our RT-PCR data show that we have good sensitivity enabling, detection of E1A mRNA in a population of transiently transfected Hep2 cells (Fig. 1C). In our set of RNA samples we could detect $\beta$-actin mRNAs (not shown) but no E1A mRNAs (Fig. 1C), indicating that expression of E1A may not be essential for adenovirus genome persistence. From the literature of adenovirus vectors we learn that E1A defective vectors have a leaky expression of the remaining genome (4) meaning a possible role of other genes in persistence. Recently E4 region has been implicated on the stabilization of a citomegalovirus early promoter driven message (13) and is candidate for a central role in adenovirus persistence. In this sense, we think that future work should point to the study of E4 region, and other potential contributors, to elucidate adenovirus persistence.

\section{ACKNOWLEDGEMENTS}

This work was supported by FAPESP (São Paulo State Research Foundation), grant 94/0578-0 and fellowships 95/1914-6 (A.A. Araújo) and 95/9823-0 (J. Yokosawa).

\section{RESUMO}

\section{Detecção de DNA de adenovírus em linfócitos humanos através da reação de polimerização em cadeia}

Seqüências de DNA de adenovirus são freqüentemente encontradas em linfócitos humanos, tendo sido utilizadas para tal as técnicas de PCR e "Southern blot". Isto é possível apesar dessas células não serem permissivas à replicação de adenovírus, sugerindo persistência do genoma viral. Para investigar esse fenômeno, procuramos detectar em voluntários não sintomáticos DNA adenoviral e expressão do gene E1A. Amostras de DNA obtidas de glóbulos brancos periféricos de 51 voluntários, foram submetidas à PCR utilizando oligonucleotídeos para uma seqüência conservada do gene hexon, seguindo-se uma "nested PCR". 
Sequiências de adenovirus foram encontradas em 27 amostras $(52,9 \%)$. Depois de mais de um ano, novas amostras desses voluntários positivos foram analisadas e em 70,8\% dos casos o resultado foi mantido. Como isto poderia ser devido à persistência, decidimos verificar se o gene precoce $\mathrm{E} 1 \mathrm{~A}$ estava relacionado analisando sua expressão através de RTPCR. Os resultados foram negativos para todas as amostras. O par de oligonucleotídeos desenvolvido para essa finalidade, que tem como alvo uma região conservada em E1A, permitiu detectar seqüências de adenovírus diretamente por PCR. A concordância encontrada entre essa análise e a pesquisa para o gene hexon foi de $84 \%$. Nossos dados sugerem alta ocorrência e persistência de genoma adenoviral em linfócitos humanos, e indicam que uma região distinta de E1A é responsável pela persistência. Podemos também afirmar que a PCR para o gene E1A é uma boa opção quando se quer detectar adenovírus, evitando-se o alto risco de contaminação da "nested PCR" necessária para identificar a presença do gene hexon.

Palavras-chave: infecção adenoviral, persistência viral, linfócitos, "nested PCR"

\section{REFERENCES}

1. Andiman, W.A.; Miller, G. Persistent infection with adenovirus types 5 and 6 in lymphoid cells from humans and wooly monkeys. J. Infect. Dis., 145:83-88, 1982.

2. Chen, I.S.; Cann, A.J.; Shah; N.P.; Gaynor, R.B. Functional relation between HTLV-IIx and adenovirus E1A proteins in transcriptional activation. Science, 230:570-573, 1985.

3. Flomenberg, P.; Gutierrez, E.; Piaskowski, V.; Casper, J.T Detection of adenovirus DNA in peripheral blood mononuclear cells by polymerase chain reaction assay. J. Med. Virol., 51:182$188,1997$.
4. Gorziglia, M.I.; Kadan, M.J.; Yei, S.; Lim, J.; Lee, G.M.; Luthra, R.; Trapnell, B.C. Elimination of both E1 and E2 from adenovirus vectors further improves prospects for in vivo human gene therapy. J. Virol., 70:4173-4178, 1996.

5. Graham, F.L.; Smiley, J.; Russel, W.C.; Nairn, R. Characteristics of a human cell line transformed by DNA from human adenovirus type5. J. Gen. Virol., 36: 59-72, 1977.

6. Hierholzer, J.C.; Halonen, P.E.; Dahlen, P.O.; Bingham, P.G.; McDonough, M.M. Detection of adenovirus in clinical specimens by polymerase chain reaction and liquid-phase hybridization quantitated by time-resolved fluorometry. J. Clin. Microbiol., 31(7): 1886-1891, 1993.

7. Horvath, J.; Palkonyay, L.; Weber, J. Group C adenovirus DNA sequences in human lymphoid cells. J. Virol., 59: 189-192, 1986.

8. Horvath, J.; Weber, J. Nonpermissivity of human peripheral blood lymphocytes to adenovirus type 2 infection. J. Virol., 62: 341-345, 1988.

9. Horwitz, M.S. Adenoviruses. In: Fields, B.N.; Knipe, D.M.; Chanock, R.M.; Melnick, J.L.; Hirsch, M.S.; Monath, M.P.; Roizman, B. (eds). Virology. Raven Press, New York, 1990, p.1723-1740.

10. Kuppuswamy, M.; Subramanian, T.; Chinnadurai, G. Separation of immortalization and T24-ras oncogene cooperative functions of adenovirus E1a. Oncogene, 2:613-615, 1988.

11. Lavery, S.M.; Lufkin, T.; Chen-Kiang, S. Productive infection of cultured human lymphoid cells by adenovirus. J. Virol., 61:1466-1472, 1987.

12. Lillie, J.W.; Lowenstein, P.M.; Green, M.R.; Green, M. Functional domains of adenovirus type 5 E1a proteins. Cell, 50:1091-100, 1987.

13. Lusky, M.; Grave, L.; Dieterle, A.; Dreyer, D.; Christ, M.; Ziller, C.; Furstenberger, P.; Kintz, J.; Hadji, D.A.; Pavirani, A.; Mehtali, M. Regulation of adenovirus-mediated transgene expression by the viral E4 gene products: requirement for E4 ORF3. J. Virol., 73:8308-8319, 1999.

14. Rota, P.A.; Khan, A.S.; Durigon, E.; Yuran, T.; Villamarzo, Y.S.; Bellini, W.J. Detection of Measles Virus RNA in urine specimens from vaccine recipients. J. Clin. Microbiol., 33(9): 2485-2488, 1995.

15. Van Der Veen J.; Lambriex, M. Relation of adenovirus to lymphocytes in naturally infected human tonsils and adenoids. Infect. Immun., 7:604-609, 1973

16. Ventura, A.M.; Arens, M.Q.; Srinivasan, A.; Chinnadurai, G. Silencing of human immunodeficiency virus long terminal repeat expression by an adenovirus E1a mutant. Proc. Natl. Acad. Sci. USA, 87:1310$1314,1990$.

17. Xie, W.Q.; Rothblum, L.I. Rapid small-scale RNA isolation from tissue culture cells. BioTechniques, 11(3): 325-327, 1991 